\title{
THE CORPORATE WASTE MANAGEMENT CONFLICT BETWEEN THE SOCIETY AND COMPANY
}

\author{
Awan Setia Dharmawan \\ (University of Muhammadiyah Malang) \\ E-Mail: Setiadharmawan@umm.ac.id / 08815501382
}

\begin{abstract}
Conflict is an attempt to achieve a certain value, status, and authority for a specific benefit as well as to defeat the opponent. The backgrounds of the study were the cause of conflict between the society and the corporate, the form of conflict between the society and the corporate, and the conflict resolution model. This study aims at finding out what caused the conflict between the corporate and the community around Badek river area, the types of conflict occurred, and conflict resolution models. This study applies the qualitative approach and is in the form of descriptive study. This study was conducted in Malang, the urban village of Sukun, Ciptomulyo sub-district. This study used purposive sampling technique to determine the subject of the study. Data collecting technique was by the observation, interview, and documentation. The theory employed in this study is the theory of conflict from Ralf Dahrendorf. The result of the study shows that the conflict between society and corporate arises because of the company's production waste pollutes the river in the environment where the community lives. The forms of conflict exist are realistic, in-group, open conflict, conflict among different classes, conflict of interest; the conflict resolution model is by using mediation with a compensation mechanism to achieve a win-win solution.
\end{abstract}

Keyword: Conflict, society, environmental pollution, environmental pollution, corporation

\section{INTRODUCTION}

The earth as a living place for humankind is attached to various significant elements which support human lives known as natural resources. Currently, there have been numerous issues on the environment in the world, both as a sole issue and with hidden agenda; one of the issues is the global warming that affects the world globally. Riley Dunlap discussed this climate change issue more detail in the eye of sociology perspective for the society and the environment (Dunlap \& Brulle:2018).

Since the early 1970s, especially after the world conference on human environment in Stockholm by the United Nations in 1972, the environmental issue has drawn the world's attention. The conference was responding various environmental damage in countries, both developed and developing countries; the issues of which are due to modern industrial activity resulting in the 
negative impact on the environment such as pollution of water, air, soil, the occurrence of acid rain, the greenhouse effect, nuclear meltdown, and other toxic waste in the nature (Iskandar, 2001:1). The data also added to a Press Release of United Nations Decade of Biodiversity; the content is about the current situation where the natural environment throughout the world has gone through various issues while the human must be able to manage the daily activities to live in harmony with nature (Press Release 2019)

Based on various researches, the environmental damage is not only due to global warming, but more than that, the issues also derive from human activities as explained in the SAGE Publication entitled Debating Alternative Development at the Minning Frontier; the article that explains about natural damages due to mining activity. The journal states a specific local saying, Buen Vivir, which means live well. This saying also means that human should live in harmony with nature. The situation becomes complex with a fact on human consumption culture which becomes a very coherent analysis in providing an added value about current human behavior towards nature, the nature exploitation to fulfill human's needs that grows more modern and changes to a consumptive community ( Consumer behaviour Research: 2016).

Based on the American Sociological Association Socius, a journal analysis, there is an unbalanced among the development of economic, consumption, and carbon dioxide emission from the year 1990 to 2014. The situation is an effect of overpopulation and an increase in human consumption have impacted in the raise of production activity, which eventually result in the emission of carbon dioxide (ASA Socius 2018)

The people of Indonesia has always lived in harmony with the surrounding and environment; most of them live in the rural area which enables them to be close to nature and have pleasant family atmosphere within the social environment. Indonesian people have always lived in harmony with nature, even in the case of remote-unknown area, yet there is a significant possibility that the country will still suffer from environmental damages in the future (Susilo,2012: 227). The risk is also affected by urban society's role in the rehabilitation stage (Parenteau \& Thong Quoc: 2005). An increase in the human population has effects not only to human but also to forests, as stated by (Anderson dan Westholm: 2019) which explained about human effort to conserve the Nordic's wood, its risk in the future, and the response from local government.

Many people believe that our nature is in the critical stage; to refer to environmental damages found everywhere. The crisis includes not only physical ones such as water, land, air, and even climate, but also biological and social environmental crisis as well ( Susilo, 2008: vii). Nature belongs to 
the biological environment, which includes natural resources to support human lives, one of which is a river (Wardiyatmoko 2006:167). The river is freshwater that flows from its source on the mainland to the inlet and empties into the sea, lakes, or other larger rivers; river flow is a stream that originates from three types of runoff which originating from rain, tributaries, and groundwater.

Rivers in Indonesian are mostly in the form of rectangular rivers, which exist in the area that has crack structure; both the real crack or merely joint. This river pattern commonly exist in Indonesia gives benefit under a proper treatment; one of the benefits is the floating market. There is also another usage of the river, for example, big European countries use it as a mean of transportation, which is already prevalent in Indonesia. Based on the background of the study, this study has several research problems, namely 1). Why there is a conflict between the society and corporate in the Sukun urban village? 2). What are the conflict forms between the community and corporate in the Sukun urban village? 3). What is the conflict resolution model between the society and corporate in Sukun urban village?

Based on the research problems, the purposes of the study are to find out the cause conflict between the society who live around Badek river and the corporate, the types of conflict exist, and the conflict resolution models.

The distinctive value in this research with other environmental conflict studies lies in the fact that there is no direct conflict and rights violation in water usage. It is different from the Bolivian Water Wars, which has direct conflict between the society and government. The Bolivian Water Wars also is about the right of water usage in responding to the privatization of water usage in Bolivia.

\section{RESEARCH METHOD}

This study applies the qualitative method by using a descriptive qualitative approach to explain the social phenomena that occurred and to describe actual event and fact that relate to the conflict between society and corporate. Therefore, the result of the study can provide a better understanding of the readers.

Bopkan and Taylor define the qualitative study as a research procedure that provides descriptive data in the form of written and oral of the object and their preferred behaviour (Moleong, 1994:3) This study occurred in Malang city, the sub-village of Sukun, Ciptomulyo sub-urban due to the existing environmental conflict in the river. The conflict arose because of the lack of ability to process corporate waste.

The main subject of this study becomes the critical primary data for the research. On the other hand, the informant as the information source to complete the data requirement was the chief of BLH Malang and the people who lived around the Badek river. The informants consisted of the inhabitant in around Badek river, a community leader, 
and three members of the Alliance of Malang Environmental-Care Society.

This study uses the data source that consists of two, namely 1), Primary data that came directly from a trusted source to assist the study with relevant data based on the title of the study. This primary data were the people who lived around the Badek river in Sukun village, the sub-urban of Ciptomulyo, Malang, and 2) Secondary data that came from Environmental Agency of Malang that supports the issue of Badek issue and also from reference as well as relevant information from the internet.

\section{THEORETICAL REVIEW}

According to Koentjaraningrat, the concept is a brief definition of a group of fact or symptom. Therefore; it can be concluded that a concept is a limitation of terms used in a particular study. In detail, the concept is a term that exists in the title of research. This study uses several concepts, namely:1), According to Lawang, conflict is a struggle to achieve value, status, authority to get benefit and conquer its opponent, 2).Conflict resolution is the attempts to solve or eliminate conflict by getting agreement between the related parties(Soeharto 2013:13), 3). According to Auguste Comte, society refers to groups of people with new developing realities based on its laws and pattern, 4). Corporate is an organization where its essential input, such as material and labour, is managed and processed to produce goods and service for the customer.
The concept of conflict, according to Marx(Abdulsyani 2002:73), refers to disagreement among segments in society to achieve valuable assets. According to Soekanto (Abdulsyani 2002:158), conflict is a social process where an individual or a group of people try to achieve a particular purpose against the opponent by using threatening or violence. Based on the explanation by Dahrendorf, a conflict may occur to every individual in general (Conflict and Critical Theory 2006). The industry is an attempt of a process to transform raw material or intermediate goods to finished goods. The finished goods have an added value to increase income. Industries have positive and negative impacts on society. There are new inventions through industrial activities for the benefit of humankind. It started with the industrial revolution in French and England, which produced various new technology. On the other hand, the industry also has negative impacts that require our attention as society members.

Social action refers to ways to express ideas and opinion under the law. Action is firmly attached to a significant amount of people and a mass demonstration on the street. Upon hearing the word action, the first thing that may cross people's mind is demonstration and pollution, which is a process when pollutants pollute the environment resulting in a decrease in its quality. The environment is every aspect in our surrounding, both the abiotic and biotic. 
Whereas, pollutants are the components of pollution, can be either foreign substances/ energies or naturally occurring contaminants in the form of chemical material, dust, heat, noise, radiation, and microorganism.

A previous study entitled "a conflict description of indigenous people of Dayak Siang, Murung, and Berkumpai against PT. Indo Muro Kencana" by Murung Raya that talks about conflict occurred in local indigenous people society. There have been many unrevealed violations on the human rights of these people in the past. The violation can be in the form of environmental pollution, customary communal land deprivation, and the eviction of people's mine by the corporate side along with the government. It is now reoccurring, leaving a significant amount of victims through the human rights violation.

The different aspect of the previous study and this current one is that the people who live in surrounding Badek river have made numerous attempts to optimize the corporate's waste processing to avoid further pollution. Another distinctive aspect is that society prefers to conduct negotiation instead of law. The relevance of this study is that both studies are that they take a similar case on the irresponsible corporate, especially in the surrounding area of the company.

Another previous study on this issue is the research entitled "Industrial's Negative Impact by PT. Semen Indonesia towards the People of Temandang village"., written by Wiwin Nur Afifah. This study discusses the construction of PT. Semen Indonesia at Temandang village has logical consequences towards the people. This study applies qualitative research method with Dahrendorf's structural conflict approach, which emphasizes the authority in the society's social structure. The result of the study shows that the associative social process occurred excellent cooperation between the community (represented by the chief) and PT. Semen Indonesia, during the condemnation of land from the farmers. The society dissociation that receives the impact of infringement and road blockade by the Tuban's NGO, an association of 1st ring, and activists who refuse the construction of PT. Semen Indonesia. There are various forms of negative impact on PT. Semen Indonesia such as the scarcity of natural resources, the consumerism of the local people, the regress and progress change of the society.

The conflict theory proposes by Ralf Dahrendorf is also knows as dialectical conflict. According to Dahrendorf, the society have two sides, namely conflict and consensus which becomes the basis for Dahrendorf to propose his significant thesis that explains about the distribution of authority, as well as different jurisdiction, determines a systematical social conflict. The power is flexible due to its attachment to a specific position instead of an individual. Therefore, an individual is possible to rule or own authority in a particular background, but not in another one ( Raho 2007: 77). 
Still, according to Dahrendorf, one can achieve an authority, not because of the personal potential but due to the different level an individual may sit in. Therefore, it will appear to rule others to achieve stability. A description of authority always serves the explanation on superordination and subordination. People who have high and significant authority is expected to be able to control the subordinates; these people who dominate due to other people's expectation in the surrounding, not because of the psychological characteristics. Authority conflict occurs when people with high authorities are against the subordinates who defend their certain rights or purposes.

\section{DISCUSSION}

This study discusses the Conflict between the Society and Corporate on Waste Management and Process. The issues on the environment, especially about water, forest, and air have high risk toward the sensitivity of local government in responding to the existing problems.

The environmental issue occurred also in Sukun sub-district of Ciptomulyo urban village whose people experienced unsuitable air for their respiratory system for the past thirty-four years. At first, there was PT Usaha Lokal that started 37 years ago, followed with PT. Kasin three years later. Both industries work in the same field, namely, tannery.

\section{The Causes of Conflict}

The conflict in this study arises due to pollution by PT. Kasin and PT. Usaha
Loka in the river that flows right under the local settlement; the situation of which is considered as being abandoned by the government. This issue has been going for thirty-four years which causes the local people of Ciptomulyo sub-urban, causing them to breath polluted air that is bad for people's health, smell that comes from the tannery waste, and as explained earlier, the people's resistance since 2001.

Unfortunately, the movement has not produced significant change such as the corporate policy to have more concern on the wastewater treatment plant. Nevertheless, the first people's movement was succeeded to have an agreement with the corporate resulting in the construction of pipes to channel the waste to avoid it ending up in the river. The following is a citation of an interview with the informant:

"dadi mas, gerakan iku (gerakan awal) Cuma sebatas melawan dengan cara yang halus, warga durung sampai melangkah ke ranah pemerintahan juga mas,cuma sebatas rapat-rapat ringan tok Mas."

"Here we go, mas, the movement (the first movement) only in the form of light of resistance and fight. The people did not try to even mention about the government domain; it was only a general meeting."

(Source: interview result with Abah Imam "Samba"). 
After this mass movement went for three months, the corporate started to recognize the strategy of Environmentalist Communication Forum. Eventually, the corporate side tried to anticipate this movement by giving support and aids to some of the movement's members, such as scholarship for children. Even the chief of the movement also received this aid from the corporate, as noted by the informant

Below is the interview result with Abah Imam "Samba" on the bribery issue:

\section{"Gerakan seng pertama biyen iku digembosi mas ambek perusahaan onok seng diparingi beasiswa, diangkat dadi security macem_macem Lah mas."}

The first movement was sabotage by the corporate, mas. They gave scholarships for children, offered a job as security guards, and many other, mas.

(Source: interview result with Abah Imam "Samba").

The fact that the corporate could easily penetrate the movement by giving money in the form of bribery affected the forum significantly, primarily since the movement chief also benefited from the action. Abah Imam "Samba" stressed that the corporate was willing to use the money to break the unity of the people in the movement. Another example is that the people who live on the other side of the railway train (RW 02) received money in the form of scholarships and job offer to work in the company. Therefore, the people started to take side with the corporate.

According to Rafi'i, the spokesman of the Ciptomulyo urban village with the government, the pollution in Ciptomulyo has become a classic issue. His statement refers to the fact that this issue was one of the problems submitted in the initial governance of Peni Suparto as the mayor of Malang. Until his second period, which ended in 2012, the Ciptomulyo pollution issue remained unsolved. Therefore, during the governance of Moch. Anton, whose motto was to care more to grassroots people, the people of Ciptomulyo tried to take the issue to the surface once again.

The second movement started in 2014 with the initiative Rozi, a new inhabitant in the area.

The following is the interview result with Rozi on the second movement action :

"Jujur mas saya merupakan warga anyar Nang Kene, tak rasa-rasakno pas aku mlakumlaku isuk ambune limbah Iki kok tambah Nemen, dadi aku inisiatif marani Abah(sapaan akrab Bapak Imam) Gae ngangkat kasus Iki”.

"Frankly speaking, I am a newcomer here, but when I had a walk in the morning, I felt the smell from the waste is getting worse. Finally, I tried to contact abah (a friendly call for Imam, 
as the chief of the forum) to talk about taking the issue to the surface for one more time."

(Source: interview result with Rozi).

Started with Rozi' initiative as a member of RT 12, the pollution issue in Ciltopmulyo has little by little taken into the surface with the hope to get the right solution. The people directly initiated to form a second movement, namely Ciptomulyo Alliance for the Environment. Abah Imam "Samba" is one more time chosen to be the chief. The movement's first agenda is to see commission $A$ and $D$ to submit the river pollution report with the help of Rofi'i.

On January 23, 2014, three of Ciptomulyo residents as the representative of RT 4, RT 9, RT 12, and RT 13 of RW 01 ask for protection from the commission due to the pollution from both corporates. During the visit to commission A of Regional Representative, Abah Imam "Samba" as the chief of RT 01 RW 06 explained that the people of Ciptomulyo have suffered from the bad smell of the waste for years. They have submitted so many protests to the corporates without any response and result. "You can go and see the river yourself; you will find out the bad smell"

There are several types of conflict, namely 1). Open conflict; it is a conflict that is visible to all parties. This type of conflict can reveal that pollution is a common issue for the public, 2). Realistic conflict is a conflict that derives from the disappointment of an individual or a group of people for a particular demand or estimated benefit, 3). In-group conflict is a conflict that occurs within a group or society, 4). Inter-class conflict is a contention between two social classes which usually occurs due to different interests between them, and 5). Interest conflict clearly appears from the corporate side to keep the existent of the company to maintain high profit, while on the other hand, the society wants to save the environment from the tannery waste pollution from both

\section{Conflict Resolution Model}

Mediation by the government must fair and all ears to listen to the people's reaction and protest to avoid having mediators that only work for a particular side or benefits. To achieve the mechanism of compensation, there are several stages to take for the government, corporate, and society:

\section{Regional Government of Malang}

a. To keep on supervise the corporates' activities during the compensation mechanism to get a win-win solution.

b. The government must issue a clear and strict regulation upon violation from both corporate and the society; the breach of which has a firm sanction.

c. review the violations from the corporates' side.

d. To have the environmental law run well on its practice. 


\section{The Corporates}

a. To do all agreements during the mediation.

b. Be consistent with providing compensation such as scholarship for poor children, not only for one time but sustainable.

c. To review the Wastewater Treatment Plant in the corporates and make renewing to tools and facilities that have direct contact with the waste treatment.

\section{The Community}

a. to build awareness for a good and healthy environment.

b. To supervise and report the corporates for any violation and harmful action for the community.

c. To rebuild the surrounding environment that needs to be fixed without asking the corporates to fund all the activities.

\section{Conclusion}

This issue in Cioptomulyo sub-urban of Sukun sub-district has come to the second generation with the same problem on the pollution by PT. Usaha Loka and PT. Kasin due to their inability to process their waste correctly. The community is still objecting with the smell that comes from the companies.

The cause of conflict is the pollution by the two corporates to its surrounding area, especially the river that exists in the community settlement and causes an unpleasant smell. Therefore, the community demands the corporates to settle this issue.

The type of conflict between the community and corporates is varied yet with the similar purpose that is to demand the right to have a clean and healthy environment based on Regulation No. 32 the Year 2009 on the environment. Fortunately, there is no anarchist movement to respond to this issue, both from the community and corporates.

The conflict resolution offered for this issue is the win-win solution with a compensation mechanism for the community in the form of CSR (Corporate Social Responsibility), scholarship program, or the closing of the sewer to minimize the smell.

\section{Reference List}

Abdulsyani. 2002. Sosiologi Skematika dan Terapan. Jakarta: PT Bumi Aksara

Dwi Susilo, Rachmad K. 2008. Sosiologi Lingkungan. Jakarta: PT Raja Grafindo Persada

Dwi Susilo, Rachmad K. 2012. Sosiologi Lingkungan dan Sumber Daya Alam Jogjakarta: Ar-Ruzz Media

Iskandar, J. 2001. Manusia Budaya dan Lingkungan. Bandung: Humaniora Utama Press

Kamus Istilah Geografi. 2010. Kamus istilah geografi. Jakarta: Rafa Pustaka

Moleong, Lexy. 1994. Metode Penelitian Kualitatif. Jakarta: Rosdakarya

Ritzer, George. 2012. Teori Sosiologi Dari Sosiologi Klasik Sampai Perkembangan 
Terakhir Postmodern. Yogyakarta:

Pustaka Pelajar

Raho, Bernard. 2007. Teori Sosiologi Modern. Jakarta: Prestasi Pustaka

Sztompka, Piotr. 2010. Sosiologi Perubahan Sosial. Jakarta : Prenada Media

Soeharto, Bambang W 2013. Menangani Konflik di Indonesia Jakarta: Kata Hasta Pustaka

Scott, John. 2012. Teori Sosial MasalahMasalah Pokok dalam Sosiologi Jogjakarta: Pustaka Pelajar

Susan, Novri.2010. Pengantar Sosiologi Konflik dan Isu-Isu Konflik Kontemporer Jakarta: Kencana Pranada Media Group

Turner, Jonathan H 1998. The Structure of SociologicalTheoryUSA: WadsworthPublishing Company

Utsman, Sabian 2007. Anatomi Konflik dan Solidaritas Yogyakarta: Pustaka Pelajar Wardiyatmoko, K. 2006. Geografi. Jakarta: Penerbit Erlangga.

\section{Non-Buku}

Koran Surya Tanggal 25 Februari Tahun 2014

Radar Malang Tanggal 23 Januari 2014

\section{Jurnal}

Allan. 2006. Conflict and Critical Theories. Social Page 211

Anderson, Westholm. 2019. Closing The Future: Environmental Research and Management of the Conflicting Future
Values Orders. Science, Technology \& Human Values/Vol 44 (2) 237-262

Chan, Kahn. 2007. Bolivian Water Wars. Environmental Governance/April. Natural Resources. 331

Dunlap, Brulle.2018.Climate Change and Society: Sociological Perspective.Human Ecology Review./Vol 24 No 1

Hogenboorm, Teijilingen. 2016. Debating Alternative Development at the Minning Frontier: Buen Vivir and The Conflict around El Mirador Mine in Ecuador. SAGE Publication/Vol 32 (4) : 382-420 Huang.Jorgensen. 2018. The Asymmetrical Effects on Economics Development on Consumption-Based and Production Based on Carbon Dioxide Emissions 1990 to 2014. American Sociological Association Socius/Vol 4: 1-10.

Kordestani, Peighambari, Pejvak, Sattari. 2016. Consumer Behaviour Research: A Synthesis of the Recent Literature./ SAGE open/April-June: 1-9.

Press Release United Nations Decade on Biodiversity 29 April 2019

Prudham. 2009. Pimping Climate Change. Richard Branson Global Warming and the Performance of Green Capitalism. Environment na Planning/April Vol 41:1594-1613.

Thong Quoc, Parenteau Rene. 2005. The Role of Civil Society in Urban Environmental Rehabilitation: a Chase Study (Thanh Xuan District, Hanoi, Vietnam). Environmental \& Urbanization/April Vol 17 